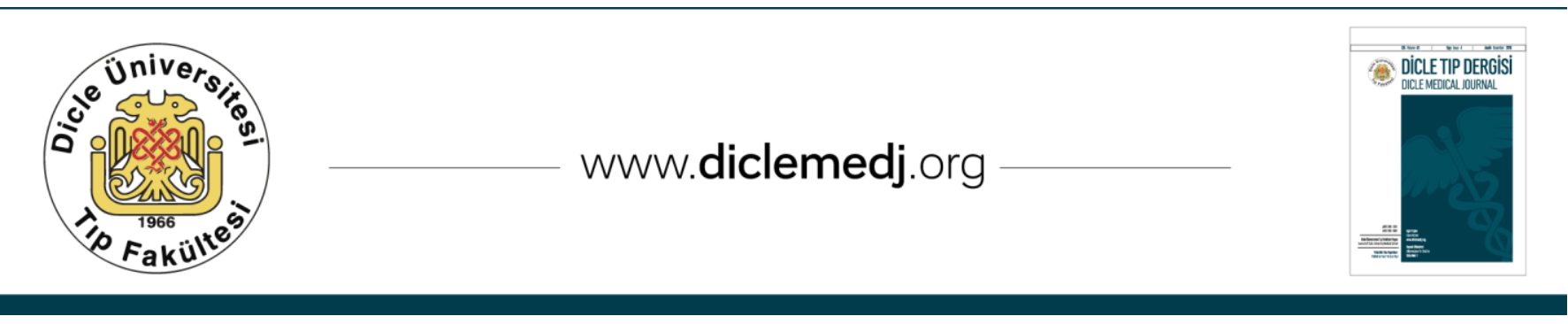

Olgu Sunumu / Case Report

\title{
A Case Report: Acute Myopia and Angle-Closure Glaucoma Attack after Topiramate use
}

\author{
Adar Aslan', Uğur Keklikçi², Kadir Bilgen ${ }^{3}$ \\ 1 Dicle University Faculty of Medicine, Department of Ophthalmology, Diyarbakir, Turkey ORCID: 0000-0003-3970-5350 \\ 2 Dicle University Faculty of Medicine, Department of Ophthalmology, Diyarbakir, Turkey ORCID: 0000-0003-2348-4856 \\ 3 Dicle University Faculty of Medicine, Department of Ophthalmology, Diyarbakir, Turkey ORCID: 0000-00032352-9639
}

Received: 06.03.2019; Revised: 24.04.2019; Accepted: 10.05.2019

\section{Abstract}

Topiramate acetate is a commonly used drug prescribed by neurologists and psychiatrists for the treatment of various diseases including migraine. Topiramate therapy can cause a forward displacement of the iris-lens diaphragm which can result in acute bilateral angle-closure glaucoma and myopia. Common complaints include visual disturbances and eye pain.

In this case report, we offered a patient who had a sudden loss of vision and severe eye pain due to acute myopia and angle-closure glaucoma after the use of topiramate for migraine. This case report aimed to increase awareness among neurologists, psychiatrists and ophthalmologists about the side effects that may occur with the use of topiramate.

Keywords: Topiramate acetate; angle-closure glaucoma; myopia; migraine; sudden loss of vision;

DOI: $10.5798 /$ dicletip.

Yazıșma Adresi / Correspondence: Adar Aslan, Dicle University Faculty of Medicine, Department of Ophthalmology, Diyarbakir, Turkey e-mail: adaraslan88@gmail.com 


\section{Bir olgu sunumu: Topiramat Kullanımı Sonrası Akut Miyopi ve Açı Kapanması Glokom Krizi}

$\ddot{0} \mathbf{z}$

Topiramat asetat başta migren olmak üzere nörolog ve psikiyatristler tarafından çeşitli hastalıklarda kullanılır. Topiramat tedavisi iris-lens diyaframının ileri doğru hareketi sonucu akut bilateral açı-kapanması glokomu ve miyopiye neden olur. Görme bulanıklığı ve göz ağrısı başlıca şikayetlerdir.

$\mathrm{Bu}$ olgu sunumunda migren nedeniyle topiramat kullanımı sonrası ani görme kaybı ve şiddetli göz ağrısı gelișen bir hastada tespit edilen akut miyopi ve açı kapanması glokomu sunulmuştur. Bu olgu sunumu ile topiramat kullanımı sonucu ortaya çıkabilecek yan etkiler konusunda nöroloji, psikiyatri ve göz hastalıkları uzmanlarının farkındalıklarını artırmak amaçlanmıştır.

Anahtar Kelimeler: Topiramat asetat; açı kapanması glokomu; miyopi; migren; ani görme kaybı;

\section{INTRODUCTION}

Topiramate acetate is used to treat the partial or generalised onset of tonic-clonic seizures, migraine, bipolar affective disorders, depression and neuropathic pain ${ }^{1}$. Bilateral glaucoma attack and acute myopia were first reported in a patient who was using topiramate as a mood stabiliser².

After the use of topiramate glaucoma attack is caused by the secondary to closure of iridocorneal angle that occurs due to the mechanical obstruction of the angle with the peripheral iris. This appositional contact is developed due to the forward displacement of the iris-lens diaphragm. This forward apposition also results in myopia.

After the ophthalmological examination, patients with primary angle-closure glaucoma, should be questioned about their history of systemic diseases and drug use. Also in these cases; the treatment should be decided according to the underlying pathophysiological mechanism $^{3}$.

In this case report, we aimed to report on a patient who developed bilateral acute angleclosure glaucoma and myopia after the use for topiramate for seeking relief from a migraine attack.

\section{CASE}

A 36-year-old woman with no history of eye disease was admitted to our clinic with severe pain and a sudden loss of vision in her eyes. In the systemic disease inquiry, the patient stated that she only had migraine and started taking topiramate about 10 days ago. She had stopped taking the drug since she had nausea after taking the first two tablets.

In the ophthalmologic examination, the autorefractometer values in right and left eye were $-3,25(-1,00 \alpha 40 \mathrm{o})$ and $-5,50(-0,25 \alpha 10 \mathrm{o})$, respectively. Best corrected visual acuities with Snellen charts in the right and left eye were found to be 0,4 and 0,8 , respectively. Intraocular pressures measured by applanation tonometry in the right and left eye were 52 and $50 \mathrm{mmHg}$, respectively. In biomicroscopic examination, bilateral corneas and lenses were found to be clear, anterior chambers were shallow, pupils were in regular sizes and irises were tilted forward (Figure1). In the gonioscopic examination, the iridocorneal angles were shown bilaterally at 'stage 0' of the treatment process, where no angle elements could be observed. The fundus examinations were natural and the cup/disc (C/D) ratios were physiological in both eyes. The patient was informed about the treatment, and 
informed consest was obtained for the treatment and its continuation.

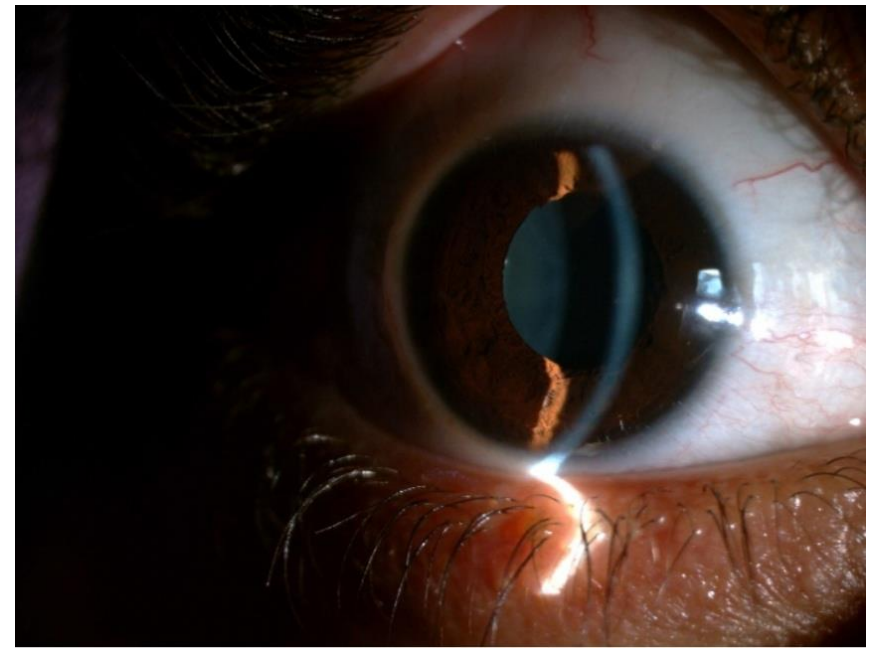

Figure 1: Shallow anterior chamber in the lower area

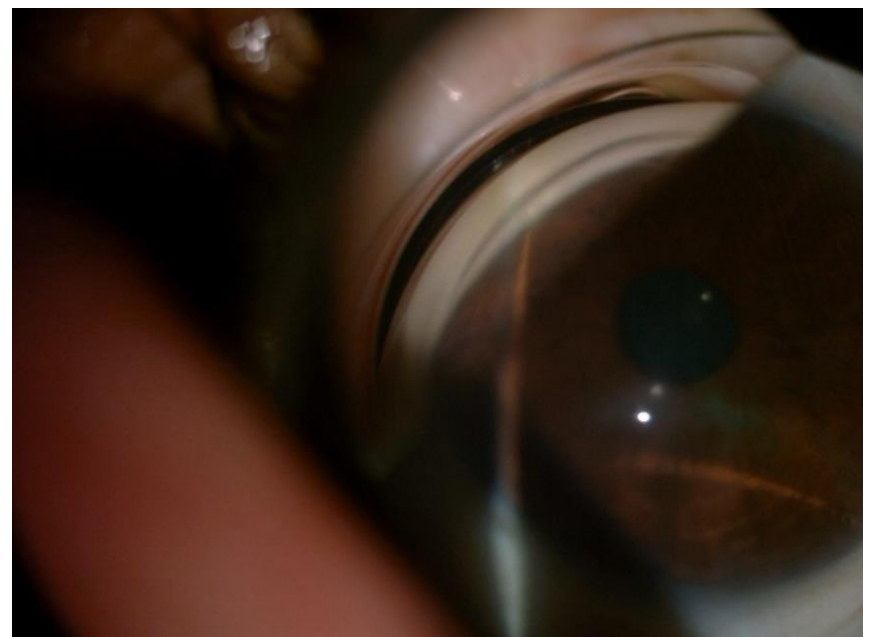

Figure 2: Irıdocorneal angle in Stage 3 of the treatment process

The patient's pain decreased after intravenous infusion treatment with $1 \mathrm{~g} / \mathrm{kg}, 20 \%$ mannitol. Subsequently, intraocular pressures in the right and lefte ye decreased to 37 and $38 \mathrm{mmHg}$, respectively. Timolol maleate + dorzolamide gtt (Cosopt, Merck Sharp\&Dohme) 2x1, brimonidine tartrate gtt (Alphagan P, Allergan) 2x1, cyclopentolat $\mathrm{HCl}$ gtt (Sikloplejin, Abdi İbrahim) 3x1, dexamethasone gtt (Maxidex, Alcon) 4x1, acetazolamide $250 \mathrm{mg}$ tablet
(Diazomide, Sanofi Aventis) 4x1 and potassium citrate+potassium bicarbonate eff tb (Kalinor, Farma Tek) 1x1 were added to the treatment regimen.

On the third day of hospitalisation, the visual acuities were 1,0/0,8 and the autorefractometric values in the right and left eye were $+0,25(-1,00 \alpha 50)$ and $+0,25 \quad(-$ $0,50 \alpha 130)$, respectively. Intraocular pressures were 11/14 mmHg. The anterior chamber returned to its normal depth, and the angles were improved in 'stage 3' of the treatment process (Figure 2). The patient was discharged with a prescription for timolol maleate+dorzolamide gtt $2 \times 1$, cyclopentolat $\mathrm{HCl}$ gtt 2x1 and dexamethasone gtt 6x1.

On the 14th day, the autorefractometric values were emmetropic and visual acuities were $1,0 / 1,0$. The intraocular pressure was $12 / 11$ $\mathrm{mmHg}$ and there were no pathology in the anterior and posterior segments. The patient's medications were stopped.

\section{DISCUSSION}

This clinical case presented here for a patient diagnosed with acute bilateral angle-closure glaucoma and myopia is related to the use of topiramate. In previous publications, it was reported that the development of acute intraocular pressure elevation and myopia started during the first two weeks of the treatment process ${ }^{4}$. Although the pathophysiology is unclear, many authors have blamed ciliary body and ciliary process oedema caused by uveal effusion ${ }^{2}$. This oedema causes an excessive loosening of the zonules and thickening of the lens thereby resulting in the forward displacement of the iris-lens diaphragm. Both forward displacement of diaphragm and thickening of the lens cause myopia ${ }^{4}$

This pathophysiologic mechanism is not only caused by the use of topiramate but also by general aneasthetic drugs, acetazolamide, 
imipramine, ipratropium bromide, corticosteroids and selective serotonin reuptake inhibitors ${ }^{5-7}$. Other than drug usage, anomalies such as microspherophakia or diseases like Vogt-Koyanagi-Harada syndrome, herpes zoster and acquired immunodeficiency syndrome should be kept in mind during the systematic evaluation of a patient ${ }^{5}$.

The first step in the treatment of secondary angle closure glaucoma due to drug use is the suspension of drug intake. Unlike primary angle-closure glaucoma, topical corticosteroids and cycloplegic agents are the mainstays of treatment ${ }^{8,9}$. Cycloplegic agents cause the retraction of the ciliary body. This helps in opening the iridocorneal angle while reducing the intraocular pressure. Miotic drugs pull the iris-lens diaphragm forward increase the angle closure and can cause pupillary block, resulting in further deterioration of the clinical situation ${ }^{10}$.

As a result, patients using these kinds of drugs should be warned about the possible side effects such as eye pain and blurred vision. In this manner, the awareness of specialists prescribing these drugs should be increased. Ophthalmologists should keep in mind the different pathophysiologic mechanisms of acute angle closure before starting the administration of a miotic agent.

Conflicts of interest: The authors have no conflict of interests to declare.

Financial Disclosure: The authors declared that this study has received no financial support.

\section{REFERENCES}

1. Thambi L, Kapcala LP, Chambers W.: Topiramateassociated secondary angle-closure glaucoma: a case series. Arch Ophtalmol. 2002; 120: 1108.

2. Banta JT, Hoffmn K, Budenz DL.:Presumed topiramate induced bilateral acute angle closure glaucoma. Am J Ophtalmol. 2001; 132: 112-4.

3. Resnikoff S, Pascolini D, Etya'ale D, et all. Global data on visual impairment in the year 2002. Bull World Health Organ. 2004; 82: 844-51.

4. Sankar PS, Pasquale LR, Grosskreutz CL.: Uveal effusion and secondary angle-closure glaucoma associated with topiramate use. Arch Ophthalmol. $2001 ; 119 ; 1210-1$.

5. Ates H, Kayikcioglu O, Andac K. Bilateral angle closure glaucoma following general anesthesia. Int Ophthalmol 1999; 23: 129-30.

6. Costagliola C, Parmeggiani F, Semeraro Fi, et all. Selective seratonin reuptake inhibitors: a review of itseffects on intra ocular pressure. Current Neuropharmacology 2008; 6: 293-310.

7. Reuser T, Flanagan DW, Borland C, et all. Acute angle closure glaucoma occurring after nebulized bronchodilator treatment with ipratropium bromide and salbutamol. J Roy Soc Med 1992; 85: 499-500.

8. Sbeity Z, Gvozdyuk N, Amde W, et all. Argon laser peripheral iridoplasty for topiramate-induced bilateral acute angle closure. J Glaucoma. 2009; 18: 269-71.

9. Örüm Ö.,TarakçığluH.,Yiğit U. : Myopic Slip Triggered by Topiramate Use and Bilateral Secondary Closed Angled Glaucoma. Turk J Ophthalm ol 2012; 42: 154-6.

10. Altıparmak UE, Akçalı Hamurcu G, Yılmaz A, Solmaz Şatana B, Duman S. Acute Bilateral Angle Closure GlaucomaDue to Topiramate Use.Glo-Kat. 2007; 2:67-9. 